\title{
The Efficiency of Tax Collection in the Czech Republic
}

\author{
Eva Tomášková*
}

\begin{abstract}
* Ing. Eva Tomášková PhD, Assistant Professor of National Economics and Public Finance, Department of Financial Law, Faculty of Law, Masaryk University, the Czech Republic. (e-mail: eva.tomaskova@law.muni.cz)
\end{abstract}

\begin{abstract}
This paper deals with the efficiency of tax collection in the Czech Republic. The first part of this paper describes theoretical approaches to efficiency of taxes. Considering the aim of the article, there are no mathematical models of efficiency presented. The second part introduces efficiency from the point of view of law. The next part involves the application of efficiency of tax collection, especially how to measure efficiency and the main barriers for its establishment in the Czech Republic. The last part of the paper offers the summing up of gained knowledge. The aim of this paper is to detect if the current approach to tax collection contributes to higher efficiency.
\end{abstract}

Keywords: qualitative efficiency; quantitative efficiency; tax collection; tax evasions; tax rate

\section{Introduction}

Total tax income and the increasing of total tax income is one of the most important issues in tax law. Politicians, lawyers and economists try to find the best way for solving this issue. This process can be characterised as a never ending story, it is still underway. All interested persons offer new solutions and then they come back to the older ways; they get inspired from the situation in other countries and they establish new taxes, then, after a time, they repeal these new taxes. These ways are changing according to the political orientation of the presenter or changing economic conditions. For this reason, the tax system is still changing and it is possible to see different tax systems in every country. Therefore, it is possible to characterise tax systems as constantly changing.

There are some requirements for tax systems. These requirements can be divided into some groups. First are general rules, which are democracy, legality, legitimacy and priority of EU law and international law. Second are rules connected with the fiscal part of financial law. There are many specific rules concerning purpose, schedules, effectiveness, efficiency, etc. ${ }^{1}$ Effectiveness and efficiency of taxes are still popular topics. There are many views on the implementation of effectiveness and efficiency, however, it is very difficult to apply these approaches in practice. Economists deal with the question how to use resources in the most efficient way to satisfy the needs of consumers. Lawyers are trying to find the most efficient way of tax processes. Politicians are comparing the efficiency of individual public goods. 
This paper describes the efficiency of tax collection in the Czech Republic. The aim of this paper is to detect whether the current approach to tax collection contributes to higher efficiency. The following hypothesis is stated: "The current approach to tax collection applied in the Czech Republic contributes to higher efficiency." Compilation, comparison, analysis and synthesis are the methods used in this contribution.

\section{The History of Attitude towards Efficiency of Taxes}

The term "efficiency" is based on the notion of Pareto optimality. It is a situation when there is no possibility to improve the welfare of an individual without making the welfare of at least another individual worse. The question is how to obtain optimal allocation and efficiency. ${ }^{2}$

However, the first written remark about efficiency of taxes is older and it is connected to Adam Smith. Smith wrote down the economic principles for taxation in his book. ${ }^{3}$ In his book, he named four maxims on taxation:

- Taxes have to be as equal as possible - every subject ought to contribute to the public budgets in the closest proportion to his or her abilities; that means in proportion to the revenue which he or she respectively earns under the protection of the state.

- Taxes have to be most certain - the amount of tax which each individual is to pay, has to be certain, clear and understandable to the contributor and for all other persons.

- Taxes have to be levied in the most convenient way and in the most convenient time for the contributor.

- Taxes have to be, as much as possible, the least burdensome to the citizens. According to Leijon: "Every tax ought to be constructed in a way that it both takes out and to keep out as little as possible of the pocket of the people, apart from what it brings into the public treasury of the state."

Several later authors agree with the approach of Smith and add more characteristics to this approach. One of the other views on efficiency relates to transaction costs. The efficiency is influenced by transaction costs. According to Coase, economic efficiency is shown in externalities, which are connected to economic allocation or outcome. Externalities create transaction costs (these costs are connected to any economic trade when participating in the market). ${ }^{5}$ Coase's theorem is based on Pareto optimality. According to Coase, a completely competitive market is without transaction costs and for this reason, it is the most efficient and brings a mutually beneficial outcome.

Musgrave and Musgrave define efficiency at production, efficiency at consumers and interaction between production and consumption. Production efficiency can be described by an example of two consumers and two products: if one production permits 10 units of $\mathrm{X}$ and 7 units of $\mathrm{Y}$ and another production permits 10 units of $\mathrm{X}$ and 5 units of $\mathrm{Y}$ the first method of production is preferred. Efficiency of a business is based on preferences of 
consumers and shows us the basic principles of good exchange. The marginal rate between the two goods ( $\mathrm{X}$ and $\mathrm{Y}$ ) must be the same for consumer $\mathrm{A}$ and $\mathrm{B}$. "The lowest rate at which $\mathrm{A}$ and $\mathrm{B}$ are willing to trade the last unit of $\mathrm{X}$ for an additional unit of $\mathrm{Y}$ should be the same for both actors." If $\mathrm{A}$ is willing to trade 1 unit of $\mathrm{X}$ for 4 units of $\mathrm{Y}$ and $\mathrm{B}$ is willing to give 5 units of $\mathrm{Y}$ in order to get 1 unit of $\mathrm{X}$, "they will exchange and a negotiation will occur as both parties gain by exchanging" ? The third condition is realised at the most efficient tax system. "The marginal rate for substitution of $\mathrm{X}$ for $\mathrm{Y}$ in consumption should be the same as the marginal rate of transformation in production that is how many extra units of $\mathrm{X}$ can be produced if one unit of $\mathrm{Y}$ is produced. If the marginal rate for consumption is $3 \mathrm{X}$ for $2 \mathrm{Y}$ but the marginal rate for production is $3 \mathrm{X}$ for $2 \mathrm{Y}$ it will be desirable to increase the output $\mathrm{X}$ and reduce $\mathrm{Y}$ until the ratio is equalised."

Niskanen deals with efficiency in the public sector and stresses that a better competitive enviroment and an increasing controlling and sanctioning system improve total efficiency. The last two instruments can be applied in the tax system as well. ${ }^{9}$

According to Taghavinezhadian, tax efficiency is most often marked as the tax effort. The success of tax efficiency includes three points. The first is the ratio of the collected taxes and allocated taxes. If the ratio equals one, the current tax system is efficient; the tax system is able to collect the taxes in the estimated level mentioned in the national budget. If the ratio is less than one or more than one, the tax system is not efficient because it gains higher income of taxes than it needs and the welfare of consumers is lower (consumers could not use the money for their own purposes) or the budget estimation has been based on unrealistic facts. The second index includes percentage changes at the collected tax in the current year and percentage changes at the collected tax in the previous year. If this index is lower than one, efficiency of the tax system decreased. If the index is one, the tax system is on the same level with the situation in the previous year. If the index is more than one, efficiency of the tax system has been increased in comparison with the situation in the previous year. Third is the relative tax rate and tax effort. ${ }^{10}$

The current changing environment brings other requirements for taxes, e.g. Salanié adds two further characteristics of taxes. The first is that taxes have to change with the economic environment; they have to be automatic stabilisers. The second one sets that taxes should be clear. ${ }^{11}$

Efficiency should be applied at allocation and distribution. Public finance tries to gain financial means to public budgets with the lowest costs and spend these financial means effectively on solving the public sector tasks.

According to Schäfer and Ott, efficiency does not involve the consideration of moral rights; it might be unjust and it does not fulfil the principles of justice and fairness. Efficiency is influenced by administrative and bureaucratic processes, the political decisionmaking process and bargaining situations. Raskolnikov notices that inefficiency can only lead to distortive taxes. ${ }^{12}$

The analysis of the above-mentioned knowledge shows that the most important characteristic for efficiency is consumer welfare. Consumer welfare is based on low tax rates and low costs related to redistribution of tax income. Some economic models were established for measuring tax efficiency. Considering the aim of the article, these models are not presented in this paper. 


\section{Efficiency of Public Administration}

Efficiency is defined in $₫ 2$ of Act no. 320/2001 Coll. on Financial Control in Public Administration and on the Amendment to some Acts (Act on Financial Control). According to this, "effective management shall mean such a use of public means for ensuring the given tasks with as little as possible provision of those means while maintaining the corresponding quality of the tasks fulfilled".

According to Mrkývka, Pařízková, Radvan et al., efficiency is evaluated through internal control system. This control system shall be independent. Internal control system involves procedures fundamental for the timely providing of information to all relevant levels of management and the elimination of shortcomings, and shall create conditions for all exercise of public administration (see $\$ 25$ of the Act on Financial Control). Control systems are necessary for the realisation of internal audit. According to $\$ 28$ of Act. No. 320/2004 Coll. on Act on Financial Control, internal audit is characterised as the evaluation of operations and internal control system of the public administration unit. It involves:

"a) the legal regulations, the measures adopted and the procedures defined are adhered to the activities of the public administration body

b) the risks relating to the activity of a public administration body are recognized on time and corresponding measures for their elimination or mitigation are adopted

c) the managing controls provided to the Chief Executive of a public administration body are reliable and timely organizational, together with the financial and other information

d) operational and financial criteria

e) the introduced internal control system is sufficiently efficient, reacts to the changes in economic, legal, operational and other conditions

f) the results achieved during the fulfilment of decisive tasks of the public administration body sufficiently ensure that the approved intentions and targets of the body shall be met" $(\$ 28)$

Internal audit involves financial audits, audit of systems and audit of execution. The aim of a financial audit is the analysis of data from accounting, financial data or data from other statements. The aim of an audit of systems is to evaluate the systems of income provision of the public administration body. Execution audits are based on the examination of effectiveness and usefulness of operations, reasonability and efficiency of the internal control system, etc.

The term "efficiency" is often mentioned in this act. Efficiency is mentioned in 21 cases and inefficiency is mentioned in 3 cases. Efficiency is often connected to management or financial control.

\section{Qualitative Efficiency}

Efficiency can be divided into two groups - qualitative and quantitative. The qualitative one is based on time analysis. Thus, the number of operations that are performed at 
a specified time is analysed. ${ }^{13}$ This time limit is often used for larger investment projects. Qualitative efficiency determines how the subject handles time. If we apply this qualitative efficiency to taxes, then it is necessary to first define the time required for all processes. Efficiency gains are related to internal tax collection processes. While it is possible to specify activities according to the necessary time, it is difficult to unify them for all activities as taxpayers and economic conditions differ. Increasing of qualitative efficiency is based on the internal processes of tax collection. It is possible to specify time for some activities; however, it is difficult to uniform time for all activities, since the taxpayers and conditions differ. Qualitative efficiency is suitable as one part of internal audit of tax offices. However, information about the number of operations realised in defined time is not published. For this reason, it is very difficult to realise an analysis of qualitative efficiency.

One possibility is to set the number of financial controls per year for every tax office and analyse if the tax offices realise the assigned numbers of financial controls. However, it is difficult to define time for all activities and internal processes. Nevertheless, it is possible to compare tax offices using their performance of finance control. The time necessary for finance control is based on many variables, e.g. the size of the taxable person, complexity of productions, the number of tax office workers etc. The public often evaluates the efficiency of tax offices according to the number or periodicity of financial controls. The last decade shows that the financial controls differ in different territories of the Czech Republic. Different tax offices performed the financial controls in intervals from 11 to 206 years between the years 2005-2013. Table 1 shows the periodicity of financial controls in the selected territories of the Czech Republic.

Table 1.

Periodicity of financial controls in the selected territories of the Czech Republic

\begin{tabular}{|l|c|l|c|}
\hline \multicolumn{1}{|c|}{ Tax office } & $\begin{array}{c}\text { Periodicity of financial } \\
\text { control in 2014 (in year) }\end{array}$ & \multicolumn{1}{|c|}{ Tax office } & $\begin{array}{c}\text { Average periodicity of financial } \\
\text { control in 2005-2013 (in year) }\end{array}$ \\
\hline Náchod & 298 & Praha 2 & 206 \\
\hline Praha 2 & 284 & Praha 6 & 161 \\
\hline Praha 6 & 277 & Praha 4 & 150 \\
\hline Praha 4 & 272 & Praha 3 & 146 \\
\hline Praha 1 & 269 & Praha 1 & 128 \\
\hline Praha 5 & 225 & Praha-Modřany & 124 \\
\hline Praha 9 & 182 & Praha 10 & 121 \\
\hline Chrudim & 175 & Praha 5 & 110 \\
\hline Praha-Modřany & 171 & Praha 9 & 107 \\
\hline Louny & 165 & Praha 7 & \\
\hline
\end{tabular}

Source: Dañové ráje a pekla v Česku. Nový žebríček finančních úradũ [Tax Paradise and Hell in the Czech Republic. New Ranking of Tax Administrators] $]^{14}$

The situation was caused by a differing number of companies in different localities. Many companies chose one of the tax offices in some districts of the capital city for the low level 
of likelihood of financial control. The General Financial Directorate has not published the average periodicity of financial control for the last years. Since January 1, 2015, all tax offices can perform financial control in all territories in the Czech Republic. It is possible to suppose that companies, which want to avoid paying taxes, will leave the market or start to pay the taxes. For this reason, it is possible to state that qualitative efficiency (improving internal processes of tax collection) is increasing. Likewise, the second factor for measuring qualitative efficiency can be the time necessary for preparation, filing and paying the taxes. According to Doing Business (Doing Business evaluates business regulations and their enforcement in 190 countries and in selected cities), time to prepare, file and pay the corporate income tax, value added or sales tax, and labour tax (including social contributions) is one of the key elements for analysing business regulation environments. It is obvious that the time spent to this preparation, filing and paying of taxes could be utilised in business more effectively. Estonia is leader in this factor. Businesspersons in Estonia need for these activities only 50 hours per year. Businesspersons in the Czech Republic need 5 times more time for filing their tax obligations ( 248 hours per year in 2018). Businesspersons in Poland need more time than businesspersons in the Czech Republic (260 hours per year). The situation in the countries neighbouring the Czech Republic is better. Businesspersons spend 218 hours per year performing all their tax obligations in Germany, 131 hours per year in Austria and 192 hour per year in the Slovak Republic. These data were valid in 2018. ${ }^{15}$

In sum, it is difficult to establish qualitative efficiency because we need to know the time needed for any related activity and internal process. There are some activities where it is possible to establish a time bound, but there are many other activities where it is impossible and generalisation is absurd.

\section{Quantitative Efficiency}

Quantitative efficiency is based on comparing real inputs and the maximum of outputs, e.g. if it is possible to gain one hundred of outputs and we gained only seventy, efficiency is $70 \%$.

It is difficult to know the maximum outputs (tax revenue). The Laffer curve shows one of its reasons; it shows the dependency of the total tax revenue on tax rate. Table 2 shows the total tax revenue including social contributions in \% GDP during the last years.

Table 2.

Total tax rate and contribution rate as \% of GDP in the Czech Republic

\begin{tabular}{|l|c|c|c|c|c|c|c|}
\hline Year & 2003 & 2004 & 2005 & 2006 & 2007 & 2008 & 2009 \\
\hline Total tax rate & 34 & 35 & 34 & 34 & 35 & 33 & 32 \\
\hline Year & 2010 & 2011 & 2012 & 2013 & 2014 & 2015 & 2016 \\
\hline Total tax rate & 33 & 34 & 34 & 35 & 34 & 34 & 35 \\
\hline
\end{tabular}

Source: Total tax revenue by country, 1995-2016 (\% of GDP $)^{16}$ 
Receipts from taxes and social contributions in \% GDP create more than one third of the total economic production in the Czech Republic. Poland has very similar total tax share (it is about $33-34 \%$ in the last years), the Slovak Republic shows about $31-32 \%$ of total share and both German-speaking countries has a higher total share (Germany about 40\% and Austria about $43 \%$ of total share). However, it is difficult to find optimal tax shares because the environment is still changing and the optimal position is changing as well.

The development of the total tax rate shows that the highest tax share in the Czech Republic was in the1990s. The level of the total share rate was $47 \%$ in 1993 . The total tax share has not significantly changed in the last fifteen years. Tax incomes are increasing although we reduce the total tax income by inflation and GDP growth.

Correia, Economides et al. notice that the increasing of tax income can be realised by increasing the progressivity of the tax system. ${ }^{17}$ It is impossible to gain more tax revenue by increasing the tax rate because people rather choose tax avoidance or tax evasion and a very high tax rate does not motivate people to activities, which are subject to tax. Ramsey offers one solution. He suggested an optimal tax rate - to have higher tax rates while taxing less elastic goods and to have lower tax rates while taxing goods that are more elastic. This rule is difficult to apply in practice; however, the total tax income would increase.

Likewise, maximum outputs at the current level of tax rate can be measured as real incomes of taxes plus incomes of tax evasion. It is impossible to add tax avoidance because it is not conveniently measurable. At first, it is necessary to detect tax evasion. Probably, there are some tax evasions that cannot be detected.

The government stresses that it wants to eliminate tax evasions and increase total tax incomes. The government has three possibilities for the elimination of tax evasions. First, to decrease the tax rate (low tax rate does not motivate people for tax evasions; the level of profit from tax evasion is not so high). Second, to impose more sanctions for tax evasions (high sanctions can be a reason why people change their minds and do not commit tax evasions). Third, to increase the periodicity of financial control. That is the most preferable method of the Government of the Czech Republic.

Tax evasions are still very high. Tax evasions ${ }^{18}$ can reach thousands of millions CZK per year. For this reason, from 2016, the government established a system of electronic records of sales. This system of electronic records is aimed at cash sales of goods and services and has to provide prompt communication between the company and the Financial Administration of the Czech Republic. It was supposed that electronic records of sales would increase the total tax income with about 18 billions of CZK in 2018. However, the total expenditures connected with the implementation of electronic records of sales are not published.

Table 3.

Total tax income in the last years

\begin{tabular}{|l|c|c|c|c|}
\hline Year & 2010 & 2011 & 2012 & 2013 \\
\hline Total tax income in bill. CZK & $548,432.3$ & $561,388.1$ & $583,746.5$ & $610,756.9$ \\
\hline Year & 2014 & 2015 & 2016 & 2017 \\
\hline Total tax income in bill. CZK & $639,199.5$ & $670,395.8$ & $732,197.2$ & $786,636.4$ \\
\hline
\end{tabular}

Source: Finančni správa [Tax Administration] ${ }^{19}$ 
Table 3 shows that the total tax income in the last years is increasing. However, it is obvious that the main reason is economic development and not electronic records of sales (total tax income was 606,896 bill. CZK in 2008 - before the economic crisis). Eurostat has the same attitude - total tax incomes of value added tax is based on economic development and the impact of electronic records of sales is very small. Moreover, some experts notice that electronic records of sales have a negative impact on the business of micro companies (because electronic records of sales bring extra costs) and do not impede tax evasions.

To summarise, the application of quantitative efficiency is difficult, as well because we need to know the maximum output for the calculation. There are some possibilities how to estimate the maximum output. Unfortunately, these numbers are only estimates with a certain probability. That is the main obstacle for the calculation of quantitative efficiency.

\section{Conclusion}

This paper deals with the efficiency of tax collection. The theoretical part includes the main notions from the perspective of economy and law. It is obvious that many politicians, economists and lawyers try to solve this issue. They made some recommendations for a better tax system and tax collection. However, there is no comprehensive solution that can be used in all tax systems. This is due to specific tax systems in each country, specific history, specific attitude of taxpayers to paying taxes, specific economic conditions, etc.

The efficiency of public administration is defined in Act no. 320/2001 Coll. on Financial Control. According to the Act on Financial Control, efficiency is mentioned in relation to management and financial control. This sense of efficiency is close to economic attitudes.

Economic theory divides efficiency into qualitative and quantitative efficiency. Both these methods are very difficult to apply in practice. Qualitative efficiency needs to establish the time needed for any activity and quantitative efficiency needs to establish the maximum outputs. For this reason, efficiency is only estimated through alternative factors such as: 1 . the number of financial controls per year; 2 . periodicity of financial controls; 3 . the time necessary for measuring qualitative efficiency (that means the time necessary for preparation, filing and paying the taxes); 4. total tax rate; 5. tax evasions; and 6. total tax incomes.

It is possible to state that the current approach to tax collection applied in the Czech Republic does not contribute to higher efficiency. The hypothesis is disproved. It is obvious that the efficiency of tax collection has to improve; it would be especially useful to reduce the time necessary for preparation, filing and paying taxes. The question is when it happens because politicians still prefer only short-term objectives and short-term outcomes and the current political situation does not indicate any positive change. Therefore, the improvement of the efficiency of tax collection in the Czech Republic will be slow. 


\section{References}

1 Petr Mrkývka, Ivana Pařizková, Michal Radvan et al. Finanční právo a finanční správa, 2. díl [Financial Law and Tax Administration, Part 2] (Brno, Masarykova univerzita, 2004).

2 Hans-Bernd Schäfer, Claus Ott, The Economic Analysis of Civil Law (Cheltenham, Edward Elgar, 2004).

3 Adam Smith, An Inquiry into the Nature and Causes of the Wealth of Nations, 676-677 (The Pennsylvania State University: The Electronic Classics Series, 2005).

4 Lena Hiort af Ornäs Leijon, Tax policy, economic efficiency and the principle of neutrality from a legal and economic perspective, 12, in Uppsala Faculty Of Law, Working Paper, vol. 2 (2015), www.jur.uu.se/ digitalAssets/585/c_585476-1_3-k_wps2015-2.pdf (accessed 21 August 2019).

5 Ronald H. Coase, The problem of Social Cost, in The Journal of Law and Economics, vol. 3 (1960). DOI: https://doi.org/10.1086/466560

6 Richard A. Musgrave, Peggy B. Musgrave, Public Finance in Theory and Practice, 61 (New York, McGraw-Hill Book Company, 1989).

7 Ibid.

8 Ibid.

9 William A. Niskanen, Bureaucracy and Representative Government (Chicago, New York, Aldine-Atherton, 1971). DOI: https://doi.org/10.4324/9781315081878

10 S. H. Taghavinezhadian, Investigation of Effects of the Organizational Structure on the Efficiency of the Direct Taxes Organization, M.A. Thesis, Tehran University, 1990.

11 Bernard Salanié, The Economics of Taxation (London, The MIT Press, 2002).

12 Alex Raskolnikov, Accepting the Limits of Tax Law and Economics, in Cornell Law Review, (March 2013). DOI: https://doi.org/10.2139/ssrn.1990430

13 Ulrike Mandl, Adriaan Dierx, Fabienne Ilzkovitz, The effectiveness and efficiency of public spending, in European Economy, Economic Papers of the European Commission, no. 301 (2008). https://doi.org/10.2765/22776

14 Daňové ráje a pekla v Česku. Nový žebriček finančnich úradü [Tax Paradise and Hell in the Czech Republic. New Ranking of Tax Administrators], 2018, https://zpravy.aktualne.cz (accessed 21 August 2019).

15 Doing Business, 2018, www.doingbusiness.org (accessed 21 August 2019).

16 Total tax revenue by country, 1995-2016 (\% of GDP), Eurostat, 2018, http://ec.europa.eu/eurostat/statisticsexplained/index.php?title=File:Total_tax_revenue_by_country,_1995-2016_(\%25_of_GDP).png; Finanćní správa [Tax Administration], 2018, www.financnisprava.cz/cs/dane/analyzy-a-statistiky/udaje-z-vyberu-dani (accessed 21 August 2019).

17 Isabel Correia, Consumption Taxes and Redistribution, in American Economic Review, vol. 100, no. 4 (2010). DOI: https://doi.org/10.1257/aer.100.4.1673; George Economides, Saqib Jafarey, Natasha Miaouli, Apostolis Philippopoulos, Consumption taxes and the efficiency-equity tradeoff, in Working Paper Series, vol. 24 (2013), Athens University of Economics and Business, https://ideas.repec.org/p/aeb/wpaper/2013024y2013. html (accessed 21 August 2019).

18 According to Police Reports, tax evasion with fuel reached 1.4 billion CZK. The company sold 276 billion litres of fuel between June 2010 and May 2011. Ukončeni vyšetrování miliardového kráceni daní [Termination of Investigations of Billion Tax Evasion], Police Reports, 2018, www.policie.cz/clanek/ukonceni-vysetrovanimiliardoveho-kraceni-dani.aspx (accessed 21 August 2019).

19 Finanční správa, supra $n .17$. 